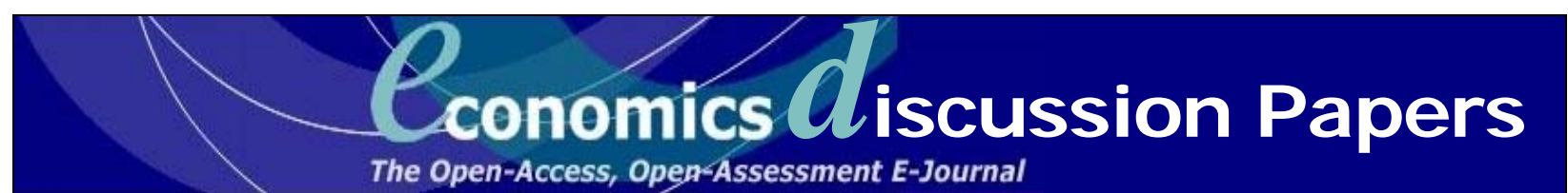

Discussion Paper 2007-31

July 13, 2007

\title{
On Policy Relevance of Ramsey Tax Rules
}

\author{
Sheikh Selim \\ Cardiff University
}

\begin{abstract}
:
The Ramsey approach to optimal taxation and Ramsey tax rules have amassed substance in economic theory. However, they are often criticized on grounds of practicality, fairness, feasibility and some other aspects of designing actual tax policy. This paper presents a collection of these views; it discusses how closely or remotely Ramsey rules are followed in designing tax policy. It presents some recent tax reforms in the US and in the UK that have closely, if not completely, followed the principle of distortion minimization. Despite the widely speculated difficulty associated with mapping normative tax rules into positive policy design, it is possible to implement taxes that have strong correspondence to Ramsey tax formulas. This paper also discusses why some implemented tax rules lack consistency with Ramsey principles, or why it is often difficult to establish correspondence between some implemented taxes and Ramsey tax rules.
\end{abstract}

JEL: $\quad$ E61, E62, H21, H30

Keywords: Optimal Taxation, Policy Relevance, Ramsey Tax Rules

Correspondence:

Dr. Sheikh Selim,Economics Section, Cardiff Business School, Cardiff University, CF10 3EU, UK;

selimst@Cardiff.ac.uk 


\section{Introduction}

Eighty years ago Frank Ramsey presented an approach to optimal taxation in an article in the Economic Journal. Ramsey's main motivation was to design an optimal tax theory that identifies the distortion minimizing tax policy and the second best levels of taxes. Today, an open set of tax rules that contains Ramsey's original tax rule and its numerous extensions, is known as Ramsey tax rules. The theory and the set of Ramsey tax rules, both of which have been through a continuous process of technical sophistication, have amassed enormous substance in economic theory. The advancement of the theory is mainly carried out by examining a range of general equilibrium models that emphasize on variations in standard assumptions regarding the decentralized market structure and equilibrium response of taxpayers. The main motivation of such extensions is to sharpen and extend the set of Ramsey tax rules. This journey has been exciting; the extent of variations in standard assumptions made and the ideas and dimensions of extensions undertaken in these general equilibrium models are captivating. This in turns has made the literature diverse, stimulating and competitive.

The practical policy relevance of these rules has been, however, often subject to criticisms. Over the last three decades the optimal tax theory and Ramsey tax rules have been criticized on grounds of their limits in designing tax policy. Important contributions in this spirit include Shavell (1981), Slemrod (1990), Heady (1993), and Alm (1996). In most parts of this particular literature, it is often argued that optimal taxation is in fact largely irrelevant to realistic tax design, because it typically abstracts from a range of considerations associated with fiscal and societal institutions that are crucial elements in the normative and positive analysis of taxation.

This paper examines the mapping of Ramsey tax rules into practical fiscal policy design. It summarizes views from a wide range of papers that have examined Ramsey tax rules from different perspectives. It explores the Ramsey tax rules beyond their second best technical properties; it attempts to evaluate their importance in addressing standard tax policy issues such as fairness, feasibility, implementability and disincentive effects. Throughout, the paper highlights the analytical strength of Ramsey tax rules and their importance and relevance in designing fiscal policy.

The quest for establishing policy relevance of Ramsey tax rules typically begins with a general (but strong) proposition: the aim of optimal tax analysis is to describe the taxes that governments should set, and not necessarily to explain the taxes that governments do set. In essence, a close relationship between the optimal tax prescriptions and the taxes that are actually implemented should not be expected. This is because there are a number of reasons for believing that governments do not follow normative approach to policy design and policy implementation. This proposition, shared equally by Slemrod (1990) and Heady (1993), however should not inhibit one from examining the correspondence between should be policy and actual policy. This paper attempts to analyze some recent tax reforms in the US and the UK that have closely, if not completely, followed the principle 
of distortion minimization. It argues that despite the widely speculated difficulty associated with mapping normative tax rules into positive policy design, it is possible to implement taxes that have strong correspondence to Ramsey tax formulas. The paper also attempts to analyze the reasons why some implemented tax rules lack consistency with Ramsey principles, or why it is often difficult to establish correspondence between some implemented taxes and Ramsey tax rules. While this analysis provides an understanding of the difficulty associated with following normative approach to tax reforms, it also identifies the areas where research on Ramsey taxation should be extended.

Before proceeding into further details, it becomes, to some extent, necessary to introduce the two stylized traditions in the optimal taxation theory A research on optimal taxation is typically based on any one of the two traditions, namely, the Ramsey tradition due to Frank Ramsey (1927), and the Mirrlees tradition due to James Mirrlees (1971). Much of the thoughts and practice of the Ramsey tradition will be the main discussion to follow in this paper. Ramsey's (1927) original idea is that in an economy with competitive markets, revenue raising second best taxes on transactions should be consistent with a set of qualifications: optimal taxes should be feasible, implementable, and associated with minimum distortion and disincentive effects. The relatively recent drift in this tradition is to examine the intertemporal equivalents of these qualifications, i.e. the optimal intertemporal pattern of distortions from average consumption taxes and a set of income taxes. There are three common features of most Ramsey taxation model 22 each model specifies a given revenue requirement for the government and a fixed set of proportionate taxes on transactions, and rule out lump sum taxes due to its impracticality; each model specifies how consumers and producers react to a particular tax policy; and each model specifies the government's objective function for evaluating different configurations of taxes. The fixed and strictly positive revenue requirement and impracticality of lump sum taxes stand as the motivation behind the problem of choosing second best taxes. The government's purely benevolent role through welfare maximization captures the ideas of distortion and disincentive effect minimization. The government's consideration for equilibrium behaviour of taxpayers for its chosen tax rates satisfies implementability and feasibility requirements. The Ramsey tradition, in general, does not consider the details of the political process that generates tax policy, and does not deal with the possibility that policymakers' objectives may be something other than benevolent. The desirability of any tax policy is evaluated solely by its

\footnotetext{
${ }^{1}$ I think the classification is a mere stylization. Contributions to the literature that follow either of these two traditions are of similar importance in designing tax policy. Put differently, and in a rather misanthropist manner, if one argues against Ramsey tax rules, similar line of argument applies to the non-Ramsey optimal taxation school of thought. A combined set of results accumulated from the two streams is more helpful in understanding the policy relevance of optimal tax rules, in general. Given the current paper's key focus, results from the non-Ramsey tradition are regarded as important mainly for a complete assessment of policy relevance of optimal tax rules.

${ }^{2}$ The current archive of papers that follow Ramsey tradition is huge and therefore establishing policy relevance of Ramsey tax rules necessitates moderating the subset of models used. The current paper only focuses on Ramsey taxation models with representative agent and full commitment (time-consistent) tax policy. I assume this is not an abstraction, rather, this is an attempt to establish the importance and policy relevance of tax rules that most closely follow Ramsey's original approach and intuitions.
} 
consequences for taxpayers.

The Mirrlees tradition, on the other hand, is more absorbed on redistribution issues and utilitarian arguments of taxation, which is why its primary focus is on marginal tax rates in an economy where agents have heterogeneous types and endowments. In this tradition, the key underlying assumption is that the optimal level of income tax depends on the consumer's ability to earn money. If the government had perfect knowledge of this ability, it could levy an ability-dependent lump sum tax that would not distort the consumer's allocation decisions. Due to incomplete information about ability, the government can only base the income tax policy on realized income. The income tax schedule can be seen as an incentive scheme eliciting information about the consumer's ability. The literature based on this tradition therefore highlights mainly the importance and policy relevance of non linear taxation of income.

The substantive lessons of taxation stemming from the two stylized traditions are, from a broad perspective, nearly similar. The important difference is perhaps their methodology and focus 33 The current paper's objective is to discuss the policy relevance of Ramsey tax rules, which is accomplished mainly by emphasizing their importance and defending them against their criticisms. The key results from the Mirrlees tradition are held as supporting arguments, which will be highlighted within the line of discussion. A summary of the key results and modelling techniques of the Mirrlees tradition, apart from the pioneering paper by James Mirrlees, can be found in Renstrom (1999).

\section{A Summary of the Discussion}

Typical criticisms of Ramsey tax rules start from the underlying assumptions and features of optimal taxation models, and practicality and political acceptability of the optimal tax rules. Most critics claim that the simplifying assumptions and some underlying features (e.g. ruling out lump sum taxes, abstraction from formal modelling of administrative costs) of standard Ramsey tax models are limitations of the theory. When Ramsey defined the optimal taxation problem, he himself clearly stated that .... I propose to neglect altogether questions of distribution and considerations arising from the differences in the marginal utility of money to different people; and I shall deal only with a purely competitive system with no foreign trade. .... (Ramsey (1927)). This paper argues that the simplifying assumptions of optimal taxation models in general (and Ramsey tax models in particular) are necessary, since elaborate attention to such details is relatively less important than the broader set of goals of the theory, which their abstraction facilitates to achieve.

\footnotetext{
${ }^{3}$ One may observe that some papers are explicitly in favour of one over the other. In essence the general principles of taxation drawn from these two traditions are more or less equivalent. It is, however, important to mention that the recent campaigners of fair taxation through progressive taxation in the US are following the line of arguments from the Mirrlees tradition, where flat tax plans are severely criticized (see for instance, Shapiro (1996)). On the other hand, flat tax campaigners are putting more emphasis on the Ramsey tradition (see for instance, Minford (2006) and Bickley (2004)).
} 
The features of Ramsey tax models that are often under scrutiny are the ones which allegedly fail to simultaneously justify fairness and efficiency of a particular Ramsey tax rule. Defining fairness of a tax system is not simple, but fairness can be an attractive feature from a political perspective. In a way, such an issue is actually addressed in most standard representative agent Ramsey taxation models, although with much less emphasis than the critics would like to see. Efficiency of tax policy is one of the main focuses of optimal taxation theory, which is reflected in the welfare maximization process of finding tax rules that reduce disincentive effects in allocation. Critics argue that greater emphasis of efficiency is associated with trading off fairness. Given a particular definition of fairness, this trade off problem is likely, and perhaps inevitable. The importance of this traed off is well documented, such as in Ballard, Fullerton, Shoven and Whalley (1985), and Piggot and Whalley (1985), which empirically examine the trade off margins of efficiency and fairness in the US and in the UK.

Critics also question the implementability and practicality of Ramsey tax rules. A Ramsey taxation model with a representative agent is particularly intended to imitate the fiscal policy design process and specify the normative benchmark average levels and composition of taxes. Without further specialization and extension of focus, one cannot expect the model to yield instrumental and applicable results that specify how such policies can be practically implemented. Moreover, Ramsey tax rules in dynamic settings in particular directly infer to the optimal average effective tax rates on the taxable transactions, which, in practical policy designing process, can be attained with a combination of different tax instruments. Finding the right combination of taxes that achieves the optimal policy, or identifying the problems associated with doing so is a different issue, and should be addressed separately. Ramsey tax rules are therefore more useful and insightful from the macroeconomic perspective (the level and composition of tax revenue) than the microeconomic perspective (design aspects of specific taxes), implying that criticizing Ramsey tax rules on grounds of practicality of tax systems is in fact far from relevant. The more useful and important way to think of the Ramsey tax rules is the correspondence between their underlying principle and tax reforms, i.e. whether or not, or how closely or remotely, a tax reform is following the underlying principles of Ramsey tax rules.

Ramsey (1927) argued that the second best tax policy should prescribe tax rates on different commodities as linked inversely to their demand elasticity, implying that necessities should be taxed heavily as compared to luxuries. This principle is strictly against the norm of uniform commodity taxation. The perception that uniform commodity taxation is optimal is quite natural. It may be sensible to assume that the lowest efficiency cost will be achieved with the fewest distortions in relative prices. Since uniform commodity taxation alters none of the relative prices of goods, it is most likely to be the optimal policy. But Ramsey (1927) shows that uniform commodity taxation is optimal only for preferences that are homothetic and separable over a number of goods. Equal tax rate on all goods except leisure increases the relative price of all goods as compared to leisure which 
results in an inefficiently large consumption of leisure. This is associated with serious efficiency loss due to suboptimal working hours, and therefore uniform commodity tax rates cannot be optimal. Ramsey argues that the optimal policy should tax complements of leisure heavily and substitutes of leisure lightly, i.e. income taxes should be low while general consumption taxes should be high in order to minimize the aggregate level of tax distortions and disincentive effects. Thus, underlying Ramsey's inverse elasticity rule for commodity taxation is the Ramsey principle: the second best tax system is one that damages everyone's incentives to work and save as little as possible.

In practice, however, uniform tax principle has led the recent policy reforms. The uniform commodity tax policy has been implemented through the introduction of VAT or GST type commodity taxation schemes. This reform agenda is primarily based on minimizing administrative costs of taxation, which I will focus in some detail later. In addition, this reform agenda often uses a reinterpretation of the Ramsey principle in favour of uniform taxation. The reinterpretation is mainly in favour of maintaining tax neutrality in tax reforms. Since raising tax rates reduces output, the loss of output is more and more damaging because of the increasing loss of value to the economy, in terms of effort being expended in pursuit of increasing real income to buy heavily taxed goods. By contrast, lowering tax rates to increase output is associated with smaller gains from that higher output because the extra value gets closer to the extra cost of the reform. If one assumes that output responsiveness is same across different markets, tax rates should be equalized; because there is no gain from switching the tax burden from, say, one commodity to another (see for instance, Minford (2006)). This intuition applies equivalently against setting differential income taxes (across sectors, say). Understandably, underlying this intuition for uniform commodity taxes there is a quest for managing a simple tax structure and creating uniform distortions in relative prices.

The quest for simplistic tax administration or the conception of tax neutrality should not be mistaken as a strong ground of criticizing Ramsey's inverse elasticity rule. The fact is that Ramsey's inverse elasticity rule is better viewed as a principle rather than a formula. The Ramsey principle says that taxes should be uniform for a set of commodities for which preferences are homothetic and separable, i.e. a set of commodities with similar elasticity of demand. The inverse elasticity rule particularly says that anything that encourages leisure (e.g. consumption) should be taxed heavily, and anything that encourages work (e.g. income or savings) should be taxed lightly. This is the underlying reason why even with VAT or GST type schemes, Ramsey's inverse elasticity rule has not totally perished from practical policy designs. There is always a set of commodities (some of which may be bads and not goods) which does not fall under the regular VAT or GST category, and are taxed relatively lightly or heavily as compared to the remaining set of commodities. A higher than VAT or GST rate tax on inelastically demanded cigarettes, for instance, is an efficient policy. First, it is associated with reduced smoking due to price incentive In addition, due to the

\footnotetext{
${ }^{4}$ Although a large number of smokers tend to act insensitively to the rise in cigarette prices, a high tax on cigarette
} 
demand inelasticity of cigarettes, a higher tax on cigarettes generates extra revenue which can be used to reduce healthcare costs, say. In the UK, for instance, the VAT is $17.5 \%$ but the effective tax rate on cigarettes is $22 \%$ of the retail price plus a duty of $£ 105.10$ per thousand cigarettes, which makes each packet of 20 cigarettes cost an additional 9 pence as compared to 2005. A zero VAT rate applies to food, books, newspapers, magazines, children's clothes and other special exempt items.

Ramsey's idea of designing optimal taxes with minimum disincentive effects and minimum distortions is reminiscent of the relatively recent idea of designing optimal taxes that create smooth intertemporal wedges in allocations. Optimal income taxes should correspond to smooth tax distortions over time, implying that the income tax-induced wedge between marginal rate of substitution of consumption and marginal rate of transformation of consumption across different dates should be uniform over time. This intuition is central to one of the most important contributions of dynamic optimal taxation theory: its lessons for capital income tax policy, which is largely due to three influential papers by Kenneth Judd (1985), Christophe Chamley (1986) and Larry Jones, Rodolfo Manuelli \& Peter Rossi (1997). The key result of these papers is that the second best policy involves zero tax on income from (physical and human) capital, and smooth and roughly constant labor income tax and consumption tax in order to finance revenues. The growth and welfare prospects and the strong underlying intuition of these principles make them more or less irrefutable and laudable in modern tax reform proposals, which is why one observes the trend of cutting down marginal tax rates on capital income in recent OECD economies' tax reforms. The pursuit for developing dynamic Ramsey tax rules has motivated important papers that address the issue of optimal income tax policy in imperfectly competitive economies. The principle of differential taxes on income and commodities, due to Stiglitz \& Dasgupta (1971), and tax favoured treatment to intermediate goods, due to Diamond \& Mirrlees (1971), motivated Judd (1997) in an attempt to reincarnate the Investment Tax Credit (ITC) scheme of the US tax code by establishing that optimal capital tax should be negative. Later, Guo \& Lansing (1999) show that with monopoly profits flowing as a fixed income to households, the government has a strong motivation to discourage profit-seeking investment by taxing capital.

If there is a criticism that characterizes a limitation of the Ramsey tradition to optimal taxation, it is the one which weakens the usefulness of standard Ramsey tax rules in designing tax policy in developing economies. An economic model that explores fiscal policy in developing economies requires particular attention to some special features, which are not typically included in standard economic models. These may be predominance of informal sector activities (which makes it difficult to identify taxable income and calculate taxable base), commercial integration (which makes the feasible margin of deviating tax policy from other countries' tax policy very restricted), and issues

purchase is likely to discourage smoking amongst middle and low income groups, or amongst the new generation of smokers, or amongst smokers who are in search of a good enough reason to quit. This is associated with improving living conditions, environment and general health. 
related to tax administration and collection. Given such unconventional features and the complexity of addressing them in standard models, tax policy in developing economies remains as the art of the possible rather than the pursuit of the optimal. It is not surprising that optimal taxation theory, as it has been practiced, will have relatively little impact on the design of tax systems in these countries. This paper includes a particular section that discusses, rather briefly, the findings of Penalosa \& Turnovsky (2005) and highlights the extent to which the Ramsey principles can be mapped into such an unconventional tax policy design problem.

\section{Optimality}

The optimality criterion of Ramsey tax rules has been through rigorous investigations, mostly on grounds of fairness, feasibility of collection and compliance, and disincentive effects. Important papers that belong to this practice are those of Shavell (1981), Slemrod (1990), Mayshar (1991), Heady (1993), Alm (1996) and Shapiro (1996). All these authors agree that the abstraction from formally modelling the costs associated with tax collection and tax compliance significantly weakens the optimality and policy relevance of optimal tax rules. More precisely, these authors argue that the second best tax policy ceases to be consistent with the theory of second best because of its abstraction from the cost of administering and implementing such a policy. Their views, however, differ in characterizing the fairness of a tax system, and thus the criticism of optimal tax rules on fairness ground remains more or less unclear.

Technically, Ramsey tax rules' optimality is rather simple and clear. Due to the impracticality associated with implementing lump sum taxes, which combined with a first best tax policy would otherwise replicate socially optimal allocations, a welfare maximizing Ramsey tax in competitive setting must be the second best policy and the associated allocations and prices must be the second best allocations and prices. This section first presents the general representation of this proposition. Mapping the second best taxes into practical tax policy design, allegedly, is far from simple. According to Heady (1993), for a tax policy to be politically desirable and implementable, the set of criteria other than simple utility maximization the policy must satisfy includes ( $a$ ) fairness; and (b) economy in collection and compliance. This paper also analyzes to what extent the standard second best Ramsey plans satisfy these additional considerations.

That the Ramsey tax rules under commitment are in general the second best outcomes can be verified by considering a general representation of the Ramsey problem with commitment in an economy with competitive markets. Consider a simple one period economy where government is committed to run its announced policy and has a technology that permits it to choose an action first, i.e. ahead of the private sector. There is a continuum of households, each of whom chooses an action $\varepsilon \in E$, in response to the government's choice of an action $\gamma \in G$. Both $E$ and $G$ are sequentially compact sets. The average level of $\varepsilon$ across households is denoted by $\bar{\varepsilon} \in E$. When 
the government chooses $\gamma$, and given that the average level of households' action is $\bar{\varepsilon}$, a particular household chooses $\varepsilon$ which gives utility $u(\varepsilon, \bar{\varepsilon}, \gamma)$. Assume that the preferences are strictly monotone in $\varepsilon$, and the utility function is strictly concave and continuously differentiable. For realized levels of $\gamma$ and $\varepsilon$, the representative household faces the following problem:

$$
\max _{\varepsilon \in E} u(\varepsilon, \bar{\varepsilon}, \gamma)
$$

The solution to (1) is a function denoted by $\varepsilon=\varepsilon(\bar{\varepsilon}, \gamma)$. With the commitment assumption, the representative household acts to set its equilibrium response $\varepsilon=\varepsilon(\bar{\varepsilon}, \gamma)$ for the government's action $\gamma$, and for the belief that the average level of other households' actions is set at $\bar{\varepsilon}$. Furthermore, if one assumes that all households are identical, then actual level of $\bar{\varepsilon}$ is $\varepsilon(\bar{\varepsilon}, \gamma)$. For expectations about the average to be consistent with the average outcome, one would require $\bar{\varepsilon}=\varepsilon(\bar{\varepsilon}, \gamma)$. A Competitive Equilibrium in this setting is an action $\bar{\varepsilon} \in E$ that is consistent with $\bar{\varepsilon}=\varepsilon(\bar{\varepsilon}, \gamma)$. A competitive equilibrium that satisfies $u(\bar{\varepsilon}, \bar{\varepsilon}, \gamma)=\max _{\varepsilon \in E} u(\varepsilon, \bar{\varepsilon}, \gamma)$ is generated by an action $\gamma \in G$ of the government. For each chosen action of the government, $\gamma \in G$, let $\bar{\varepsilon}=\xi(\gamma)$ denote the corresponding competitive equilibrium. The set of competitive equilibria is therefore defined as $C=\{(\bar{\varepsilon}, \gamma) \mid \bar{\varepsilon}=\xi(\gamma)\}$.

The Ramsey problem is the planner's (in this case, the government's) problem of choosing an action $\gamma \in G$ that maximizes welfare such that the resulting actions of the households are implementable in a competitive equilibrium. The Ramsey problem for the government is $\max _{\varepsilon \in E} u(\xi(\gamma), \xi(\gamma), \gamma)$. Let $\gamma^{R} \in G$ denote the policy that attains the maximum of the Ramsey problem. The Ramsey plan is $\left(\gamma^{R}, \varepsilon^{R}\right)$ where $\varepsilon^{R}=\xi\left(\gamma^{R}\right)$. The Ramsey plan in this setting is a result of the following sequence of actions. First, the government chooses $\gamma \in G$. Knowing the setting of $\gamma$, the households respond with $\bar{\varepsilon} \in E$, such that $\bar{\varepsilon}=\varepsilon(\bar{\varepsilon}, \gamma)$. The government is benevolent, i.e. it evaluates its set of actions (which could be a set of policies) $\gamma \in G$ on the basis of welfare maximizing motive. More specifically, the government chooses a particular action $\gamma \in G$ that (a) maximizes $u(\varepsilon, \bar{\varepsilon}, \gamma)$, and (b) is consistent with the government's correctly foreseen equilibrium reaction of households, $\bar{\varepsilon}=\xi(\gamma)$. By contrast, a benevolent dictator would simply choose a pair of actions that solves the problem $\max _{\varepsilon \in E, \gamma \in G} u(\varepsilon, \varepsilon, \gamma)$. Any such pair, say $\left(\gamma^{F}, \varepsilon^{F}\right)$ replicates the socially optimal outcom $\AA^{5}$ In general such outcomes cannot be reached under a decentralized regime, which stands as the key

\footnotetext{
${ }^{5}$ For instance, if $\gamma$ represents a complete set of tax instruments on transactions, $\gamma^{F}$ is the policy that sets zero taxes on all transactions and raises all revenue by a single lump sum tax. For a competitive setting that involves intertemporal decision-making, a sequence of fixed revenue requirements can be satisfied by a sequence of fixed lump sum taxes and a sequence of zero tax on transactions involving period by period decisions (e.g. labor supply) and intertemporal decisions (e.g. capital accumulation). This lump sum tax is fixed for all households irrespective of the level of their endowment or income. This policy is associated with no efficiency loss since it does not influence the working, consumption or saving decisions of a household. In addition, if there are pre-existing distortion in the economy that pushes private return to factors lower than socially optimal returns, $\gamma^{F}$ involves corrective subsidies (to push up the private return at the level of optimal return) and a larger-than-government-revenue lump sum tax to finance the subsidy.
} 
motivation behind looking for the second best solutions. Consider, however, the outcome where the government's action is dictatorial, i.e. without any consideration of the equilibrium feedback. Surely the Ramsey plan $\left(\gamma^{R}, \xi\left(\gamma^{R}\right)\right)$ is inferior to the dictatorial outcome $\left(\gamma^{F}, \varepsilon^{F}\right)$, because the restriction $(\gamma, \varepsilon) \in C$ is in general binding. Moreover, in general $\varepsilon^{F} \neq \xi\left(\gamma^{F}\right)$, so first best outcomes are not Ramsey plans.

More intuitively, the dictatorial outcome in such a setting would imply that the government may replicate a socially optimal outcome by choosing $\gamma^{F} \in G$, if for any $\varepsilon \in E, \varepsilon \leq \varepsilon^{F}$, and the government does not take into account the competitive equilibrium reaction $\bar{\varepsilon}^{F}=\varepsilon\left(\bar{\varepsilon}^{F}, \gamma^{F}\right)$. As long as the action $\gamma^{F} \in G$ is practically implementable, it can be implemented without any consideration of $\bar{\varepsilon}^{F}=\varepsilon\left(\bar{\varepsilon}^{F}, \gamma^{F}\right)$. Since preferences are strictly monotone and $\varepsilon \leq \varepsilon^{F}$ for any $\varepsilon \in E$, the action $\gamma^{F} \in G$ does not distort welfare through its effect on households' equilibrium decision, implying that it would attain first best optimality, i.e. $u\left(\bar{\varepsilon}^{F}, \bar{\varepsilon}^{F}, \gamma^{F}\right) \geq u(\bar{\varepsilon}, \bar{\varepsilon}, \gamma)$. On the other hand, if the action $\gamma^{F} \in G$ is not practically implementable, the government's next best alternative is the Ramsey plan $\left(\gamma^{R}, \xi\left(\gamma^{R}\right)\right)$, which solves $\max _{(\bar{\varepsilon}, \gamma) \in C} u(\bar{\varepsilon}, \bar{\varepsilon}, \gamma)$. The corresponding action $\gamma^{R} \in G$ is welfare maximizing, but it induces efficiency loss relative to the first best outcome since it distorts the households' competitive equilibrium allocation decisions. The welfare maximizing Ramsey policy is therefore associated with the minimum loss of welfare from the $u\left(\bar{\varepsilon}^{F}, \bar{\varepsilon}^{F}, \gamma^{F}\right)$ margin and therefore attains second best optimality.

\section{4 'Fairness' of Second Best Taxes}

What actually is a fair tax policy? Heady (1993, p. 17) wisely asserts that "fairness of a tax policy means different things to different people". Though not due to this one-dimensional reason, the critics of optimal taxation theory generally differ in ideological characterization of fairness of a tax system or tax policy. This is not surprising, since fairness itself is an obscure feature and its characterization requires adhering to proxy features of tax systems such as progressiveness, equity and compliance. From a policymaker's point of view, a fair tax system means a tax system free of favouritism or self-interest or bias or deception. This definition is conventional, and perhaps fair. Other than this, fairness of a tax system in essence can have different interpretations in different groups of taxpayers. In the optimal taxation literature, a fair tax system is typically characterized by attaching different weights to horizontal and vertical equity (see for instance, Shapiro (1996) for details), minimization of inequality (see for instance, Shavell (1981) for details), and tax compliance

(see for instance, Alm (1996) for details). The current analysis of fairness is limited to the first two concepts, while the issue of tax compliance is deferred to the section analyzing administrative costs of taxation.

Most critics, irrespective of their stand on defining fairness, claim that Ramsey tax rules lack fairness mainly due to Ramsey tradition's key emphasis on efficient taxes. There is a trade off be- 
tween efficiency and equity of a tax system, which perhaps is an inherent feature of any tax policy The broad objective of Ramsey taxation is minimizing inefficiency of taxes, and from a macroeconomic perspective establishing the importance of equity of a second best policy is somewhat obscure. In the relevant literature, except for Judd (1985) and Ljungqvist \& Sargent (2000, ch.12) who use models with heterogeneous agents and lump sum transfers, the issue of equity is typically simplified by assuming that all taxpayers are identical in tastes and endowment. Renstrom (1999) argues that such simplifications of Ramsey models induce a trade off between efficiency and both vertical and horizontal equity, and greater emphasis of efficiency and abstraction from equity limits its policy practicality. As is clear by now, the trade off argument is somewhat undeniable. The issue is therefore the cost of this trade off, or more precisely, the opportunity cost of emphasizing efficiency.

The efficiency-equity trade off debate can be partly resolved if one considers the relative importance of these two rather abstract principles. Consider for instance the issue of vertical equity. A tax policy is fair in terms of vertical equity if the tax burden is consistent across taxpayers of different means. This is the typical focus of the Mirrlees (1971) tradition of optimal taxation. A standard Mirrlees-type approach with heterogeneously endowed agents essentially finds that the resulting optimal non-linear tax rules are consistent with vertical equity, and thus one might argue that these rules are fair tax rules. This intuition is conceivable, but commodity taxes which vary with the circumstances of the buyer are in general impractical.

Ramsey's inverse elasticity rule states that more inelastically demanded goods tend to attract higher tax rates. The efficiency cost minimizing commodity taxes will therefore in general differ by commodity. Any tax on transactions involves a loss of consumer surplus. The loss in consumer surplus is greater if demand is more elastic, implying that the rise in the price facing a consumer from the tax will lead to a larger reduction in quantity purchased than if demand were more inelastic. Moreover, if all goods except leisure are taxed at the same rate, a reduced relative price of leisure leads to an inefficiently large consumption of leisure. The optimal tax pattern should take advantage of commodities' relative substitutability and complementarity with leisure. A complement to leisure should be taxed relatively heavily, and a substitute for leisure should be taxed relatively lightly. Given this intuition, in principle, the issue of equity ceases to be of major importance here. The

\footnotetext{
${ }^{6} \mathrm{~A}$ first best policy which involves zero taxes on transactions and a lump sum tax, for instance, is the most efficient tax policy since it is associated with minimum disincentive effects. But such a first best policy is the least fair tax policy unless taxpayers are identical and have identical endowments. To illustrate this idea further, consider a hypothetical situation where the taxation authority seeks to raise a given amount of revenue to finance local government expenditure, and has the option to implement a flat community charge or a proportionate local income tax. In choosing between the two, most taxpayers would regard the local income tax as fairer. But a local income tax would have a greater disincentive effect on labor supply than the community charge. In order to choose a policy, it is therefore necessary for the authority to weigh the fairness advantage of the local income tax against its disadvantage of discouraging work. The main theme of optimal taxation theory is to create welfare maximizing tax policy which has minimum disincentive effect on allocations. In this sense, the fairness advantage of local income tax is likely to be out-weighed.
} 
concern of efficiency is one of major importance, since welfare maximizing (but distorting) taxes should reflect the advantages of incentive effects more than the advantages of fairness. Too much attention to equity may be associated with allowing for too much inefficiency, resulting in too much distortion in intertemporal allocations.

An alternative (and perhaps more practical) view of fairness is associated with inequality, which in turns is related to social welfare. In Ramsey tax models, social welfare is seen as an indicator of well being of society and is taken to depend on the utilities of individuals. In its simplest setting, social welfare is defined by the utility of the measure one of households. Social welfare can also depend on how equally these utilities are distributed as long as agents differ in endowments. In the utilitarian school of thought it is typically assumed that social welfare decreases as inequality increases. In this way, the concept of social welfare captures one idea of fairness of a tax system. Taxes are fair if they reduce the degree of inequality, implying that attempt to maximize welfare will involve an instantaneous attempt to achieve fairness. Given this idea, the social welfare function must place more weight on utility gains of poor people than those of rich people, which is one of the main motivations of the heterogeneous agent redistributive taxation models typically used in the Mirrlees tradition. However, this does not imply that it is strictly necessary to follow the Mirrlees methodology to derive such insights. Judd (1985) and Ljungqvist \& Sargent (2000, ch. 12) show that a Ramsey model with heterogeneous agents and optimal redistributive taxation can actually recover the key findings of the optimal redistributive taxation that follow the Mirrlees tradition, and that, perhaps at a relatively lower cost of methodology.

The real-world campaign for fair tax systems is an interesting move that is observed mainly in major industrialized economies. Establishing that the key manifesto of these campaigns is based primarily on Ramsey rules is not difficult. The concept of a fair tax in the US is one of a single-rate, federal sales tax collected only once, at the final point of purchase of new goods and services for personal consumption. If implemented, as the campaign demands, it replaces federal income taxes including, personal, estate, gift, capital gains, alternative minimum, social security, medicare, selfemployment, and corporate taxes. The US concept of fair tax, therefore, imposes a single rate tax for all buyers independent of the level of their wealth. Since buyers with higher wealth spend more money than other individuals, the amount of tax that they pay will be more than other individuals. On the other hand, the idea that every household receives a rebate that is equal to the fair tax paid on essential goods and services claims that the policy is fair to middle and low income groups. Relatively elastic goods and activities, such as financing research and development, donations to charities, employment generation, are tax favoured. Since the relatively wealthier individuals are likely to spend on these activities, they will spend more in order to reduce their tax burden on consumption expenditure. More spending on these activities will foster growth and welfare for the middle and low income groups.

In the UK, the concept of a fair tax is interpreted through the campaign of a flat tax system. This 
campaign actually originated from the campaign of implementing a flat (irrespective of locality) council tax rate. In its pure version, a flat tax replaces multiple marginal tax rates with a single marginal tax rate, and abolishes the complex systems of allowances and tax relief. Under the flat tax principle personal allowances are unjustifiable because they imply a rise in the necessary flat rate of tax. In addition, the campaign demands lower generosity in providing tax credits and benefits, because these welfare tools, though worthy of their own purposes, are expensive in taxes which drags down the welfare and efficiency of the general taxpayer. All taxes, corporate, personal income, and VAT, are set at the same rate, amounting in effect to a consumption tax which abolishes any double taxation (e.g. taxation of dividends). The advantages of a flat tax are its simplicity and transparency, leading to faster economic growth due to greater incentives to work, and the removal of various disincentives and distortions caused by existing tax distortions, including the creation of large black markets through tax avoidance and evasion. These advantages have been apparent in the many East European countries including Russia, Estonia, Latvia, Ukraine, Georgia and Romania, which, whilst moving from the plan to the market, have adopted flat taxes. The prime feature of both the US fair tax campaign and UK flat tax campaigns is creating a simple, distortion minimizing and welfare improving redistributive tax system, all of which are essential characteristics of Ramsey tax rules.

\section{Administrative and Compliance Costs}

Perhaps the most severe criticism of the optimal taxation theory stems from its moderate attention to the details of administrative and compliance costs of taxation. A compelling survey of such criticisms can be found in Alm (1996). Administrative and compliance costs are actually important issues from the perspective of design and implementation of specific taxes. However, they are not so important if one is only concerned about the average level and composition of taxes. In representative models of Ramsey taxation that deal specifically with the average level of taxes, minimizing administrative costs will be reflected in social welfare, because higher administrative costs will require a greater amount of gross revenue to be collected that reduces individual utilities.

There have been attempts to formally include administrative costs in optimal taxation models. To my knowledge the seminal attempt is of Yitzhaki's (1979), which presents a simple static model of optimal commodity taxation with administrative costs where the aim of the taxation authority is to minimize the social cost of taxation 7 . According to his specification, the social cost of taxation is the sum of the administrative cost and the deadweight loss caused by the tax system. By varying the number of feasible tax rates, Yitzhaki (1979) finds that the relative effect of administrative costs

\footnotetext{
${ }^{7}$ A relatively more recent attempt to model administrative costs in optimal taxation model can be found in Mayshar (1991), which derives the conditions that characterize the optimal use of the tax assuming that there are costs to both the taxpayer and the government from collecting a generic form of taxes.
} 
worsens the optimality of the second best policy. This is why one of his conclusions was that if one allows the number of feasible taxes to vary, the optimal taxation problem with cost of collecting taxes ceases to be a problem in the theory of the second best.

While his assumption of varying tax instruments is tempting, it is not consistent with second best taxation theory. Obviously, if one allows the number of taxes to vary to account for variable government expenditures, the second best optimality of Ramsey policy is in question even without explicit modelling of administrative costs. Varying government expenditure essentially relates to a trivial solution, i.e. set government expenditure equal to zero and do not use distorting taxes. On the other hand, with strictly positive government expenditure if one allows the number of tax instruments to vary, a trivial solution may be to eliminate all distorting taxes, or set all distorting taxes equal to zero, and use a lump sum tax equivalent to raise the required revenue. This particular solution is likely to replicate first best allocations, but as agreed by many, large lump sum taxes lack practicality.

Even if one relies on Yitzhaki's (1979) interpretation that administrative and compliance costs of taxation is a proportion of the social cost of taxation, it is difficult to find a good enough reason to model it formally. A shadow measure of the social cost of taxation can be captured from the deviation of second best welfare from the first best welfare. An implementable set of distorting taxes induces a deviation from competitive equilibrium welfare which is essentially captured in the planner's programming problem. More precisely, the planner's welfare maximizing problem involves, in addition to the resource constraint, a constraint that restricts welfare maximizing taxes to be implementable. This means that the Ramsey planner can choose taxes that generate a set of equilibrium allocations (and prices) that is purely consistent with taxpayers' equilibrium allocations (and prices). This added restriction in the planner's problem is associated with a present value cost of a sequence of tax plans, i.e. the discounted social cost of administering the distorting tax policy. This social cost of taxes therefore is representative of administrative costs of taxes. To see the matter more formally, consider for instance, a very standard one sector neoclassical growth model of Ramsey taxation, more in the spirit of Ljungqvist \& Sargent (2000, ch. 12).

Following the example we have set previously in this paper, say an infinitely extended family has endowments of one unit of time at each period and $k_{0}>0$ units of capital to start with, and set of actions $\varepsilon=\left\{c_{t}, n_{t}, k_{t+1}\right\}_{t=0}^{\infty}$, where the actions are consumption, labour supply and one period ahead capital allocation. There is one good in the economy, its level is $y_{t}$, and it is produced using raw labour and capital according to technology $\phi\left(k_{t}, n_{t}\right)$, sold in a competitive market, and is used for consumption and investment. The economy's resource constraint is:

$$
\phi\left(k_{t}, n_{t}\right)-c_{t}-g_{t}-k_{t+1}+(1-\delta) k_{t}=0 ; \quad \delta \in(0,1)
$$

We will define the government's set of actions as $\gamma=\left\{\tau_{n t}, \tau_{k t}, g_{t}\right\}_{t=0}^{\infty}$, where the first two 
are tax rates on labour income and capital income, and $g_{t}$ is exogenously determined government purchases. We will assume that the government runs a balanced budget each period. $\phi($.$) satisfies$ standard regularity assumptions. Competitive pricing ensures that factors are paid their marginal products, and in equilibrium, wages and rental rate of capital are $w_{t}=\phi_{n}(t)$ and $r_{t}=\phi_{k}(t)$. The representative family chooses actions $\varepsilon=\left\{c_{t}, n_{t}, k_{t+1}\right\}_{t=0}^{\infty}$ in order to maximize discounted lifetime utility $\sum_{t=0}^{\infty} \beta^{t} u\left(c_{t}, 1-n_{t}\right)$ subject to the following budget constraints:

$$
w_{t} n_{t}+r_{t} k_{t}+(1-\delta) k_{t}-k_{t+1}-c_{t}-T_{t}=0
$$

where $T_{t}$ is the total taxes paid to the government, and $g_{t}=T_{t}$. The utility function $u($. satisfies standard regularity assumptions. A competitive equilibrium in this economy is a set of actions $\varepsilon=\left\{c_{t}, n_{t}, k_{t+1}\right\}_{t=0}^{\infty}$, prices $\left\{w_{t}, r_{t}\right\}$ and government's actions $\gamma=\left\{\tau_{n t}, \tau_{k t}, g_{t}\right\}_{t=0}^{\infty}$, such that given the prices at equilbirium and government's actions, the actions $\varepsilon=\left\{c_{t}, n_{t}, k_{t+1}\right\}_{t=0}^{\infty}$ solve the maximization problem of the representative family and satisfies 22. Given $g_{t}, k_{0}>$ 0 , the government chooses tax rates to maximize welfare such that these taxes are feasible and implementable, i.e. the allocations and prices generated by these welfare maximizing taxes satisfy (2) and the competitive equilibrium. Put differently, the government's welfare maximizing taxes should generate a set of allocations and prices which is one element in the set of possible competitive equilibria generated by different tax rate combinations. One can thus characterize the Ramsey planner's problem as one of choosing allocations to maximize utility subject to (2) and the following implementability constraint:

$$
\sum_{t=0}^{\infty} \beta^{t}\left[u_{c}(t) c_{t}+u_{n}(t) n_{t}\right]-u_{c}(0)\left[\left(1-\tau_{k 0}\right) \phi_{k}(0)+1-\delta\right] k_{0}=0
$$

which is derived by using competitive equilibrium conditions to substitute out prices and taxes from the present value version of (3). In order to solve this problem, one can conveniently define a Pseudo-type utility function, or more intuitively, the second best welfare function:

$$
\Gamma\left(c_{t}, n_{t}, \eta\right) \equiv u\left(c_{t}, 1-n_{t}\right)+\eta\left[u_{c}(t) c_{t}+u_{n}(t) n_{t}\right]
$$

where $\eta \geq 0$ is the Lagrange multiplier on (4). Intuitively, $\eta$ provides a shadow measure of the utility cost of raising government revenues through distorting taxation. Given the Ramsey programming problem, say $\Gamma^{*}($.$) is the maximum value of \Gamma($.$) . Thus \Gamma^{*}()=.u^{*}()+.\eta^{*}\left[u_{c}^{*} c^{*}+u_{n}^{*} n^{*}\right]$, i.e. the second best level of welfare, is equal to first best level of welfare less the loss in welfare due to distorting taxes. The loss in welfare is measured in terms of loss in allocations due to competitive equilibrium reaction of taxpayers, which is multiplied by the shadow price of taxes, $\eta$. This multiplier's value is representative of the amount in terms of consumption taxpayers are 
willing pay in order to replace a unit of distorting tax with a unit of lump sum tax. If one assumes that lump sum taxes are less costly to administer, the utility cost of distorting taxes actually represents a broader measure of administrative costs of taxation. For instance if the value of this multiplier is high, the social cost of distorting taxes is high but that of lump sum taxes are low, implying that administering the second best tax policy costs relatively higher amounts of forgone consumption. Representative Ramsey taxation models thus simplify the social cost of taxation with one multiplier, and this formulation is very standard in both static and dynamic Ramsey taxation frameworks. Moreover, it is well-known that in an imperfectly competitive economy optimal taxes can be very effective in neutralizing monopoly distortions. This is the reason why the value of this multiplier is likely to be smaller with imperfectly competitive markets and relatively larger with competitive market, implying that in terms of forgone consumption, administering a second best tax policy is relatively less costly in economies with lesser amount of competition.

In the real world, administering and collecting taxes can be overwhelmingly costly. Interesting evidence of such costs is provided by Slemrod (1990) and Alm (1996). For instance in the US, operating the tax system requires the participation of over 100 million taxpayers, hundreds of thousands of tax professionals, and a multi-billion dollar budget for the Internal Revenue Service and its state subsidiaries. Apart from such direct costs, there are costs of tax compliance, tax evasion and creating the ease of administering taxes. Alm (1996) reports that for the US economy the budget cost of collecting individual income, business income, and sales tax is generally in excess of $1 \%$ of the revenues from these taxes. The approximate average compliance cost of personal and corporate income taxes for the US economy range from $3 \%$ to $7 \%$ of their revenue, while for UK and Australia these figures range from $2 \%$ to $24 \%$ of revenues for selected taxes.

In addition, there are discrete changes in compliance costs for any budgetary reforms of tax rates, tax relief, or allowances. This makes the design of tax reforms more complicated. It is, however, very likely that a tax reform aimed at minimizing distortions by simplifying the collection and administration of a tax will lower the compliance costs of that particular tax. To see this more clearly, consider the 2006 budgetary reform of the UK government that replaces the Non Corporate Distribution Rate (NCDR) and the starting rate of corporation tax with a single small companies' rate. Prior to this reform, the 2004 budget introduced a $19 \%$ NCDR to ensure the incentive was focused on profits retained by small companies. This NCDR was charged on any profits distributed as dividend payments to individuals, rather than retained in the company to fund investment 8 The Regulatory Impact Assessment (RIA) for the NCDR published in April 2004 estimated only

\footnotetext{
${ }^{8}$ The starting rate of corporation tax was introduced in 2000 and reduced from $10 \%$ to $0 \%$ in 2002 . It applied to companies with profits up to $£ 10,000$ per year, with marginal relief for companies with profits between $£ 10,000$ and $£ 50,000$ per year. Above this level, profits were taxed at the small companies' rate of $19 \%$ (up to a threshold of $£ 300,000)$. After the reduction of the starting rate to $0 \%$, concerns were raised that the benefits of the rate were being used by incorporations not intending to grow. Therefore, at Budget 2004 the NCDR was introduced to ensure the incentive was focused on profits retained by small companies. The NCDR charged $19 \%$ on any profits distributed as dividend payments to individuals, rather than retained in the company to fund investment.
} 
a modest increase on the then existing compliance costs for small companies. However, the recent RIA indicates that the compliance costs related to implementation of the NCDR were significantly greater than originally estimated. This is because compliance cost of discrete reforms requires a company to calculate the corporation tax which would be due if the NCDR did not exist, and thus establish the underlying rate of tax. In addition, the company has to establish the amount distributed through dividends to persons other than companies, apply the NCDR rate to that amount of non corporate dividend, and apply an underlying rate to the balance of taxable profits. The partial RIA of 2005 estimated these compliance costs to be in the region of $£ 35$ million per year. The most recent RIA revised the figure on the number of companies affected by the NCDR and the recent change of NCDR into a small companies' rate. This revision suggests that the compliance costs are $£ 23$ million per year, assuming the total compliance time for a company to be 1.5 hours and that their time costs $£ 50$ per hour.

In general, there is little information on how these costs vary with various tax instruments and tax bases. It may be that administrative costs vary in large and discrete amounts with the scale of collections, or with the particular transaction which is taxed, or variations in tax instruments that necessarily includes variations in tax relief. These hypotheses are roughly similar to Yitzhaki's (1979) one of discontinuous administrative costs for changes in tax base. This is more likely to be the main reason why most parts of optimal taxation literature abstracts from modelling these costs formally. Administrative and compliance costs of taxation do not vary continuously with taxes, but they tend to vary with such things as the number of different rates of tax or the number of tax allowances. This makes them difficult to include in the mathematical analysis of general equilibrium models.

\section{6 (Dis) incentive Effects}

It is a simple understanding that paying a higher tax bill is not possible without reducing consumption, increasing income, reducing savings or increasing borrowing. Tax reforms, such as changing marginal tax rates or personal allowances can affect a number of relative prices, which in turns affect behavioural choice, resource allocation, and real economic activity. In particular, tax-induced relative price changes affect choices between work and leisure, consumption and future consumption, and taxable and non-taxable activity. In representative agent frameworks, optimal taxation theory formalizes these responses to taxation in a manner that is consistent with the specification of utility and intertemporal allocation decisions.

Modelling disincentive effects in a standard optimal taxation framework is likely to be selective, however. This is the standard practice, and there are strong reasons, such as tractability, for doing

so. For instance, income taxation can have significant effects on decisions other than labour supply, which may be savings decision, consumption plans and human capital formation (e.g. educational 
choice). Most standard Ramsey models look at these disincentive effects either in conjunction with labour supply or separately, but in most models there is no attempt to combine them all. This is because the imminent complexity associated with such models would be too substantial to yield any clear insights.

Selective modelling of disincentive effects however does not limit the usefulness of Ramsey tax rules in explaining the incentive structure underlying a policy. The intuition, once again, stems from characterizing the mapping of aggregate levels of optimal taxes into specific tax instruments. To explain this intuition, consider first that the Ramsey tradition of optimal taxation assumes an exogenous level of government expenditure and a fixed set of feasible tax instruments. The assumption of a preset (and nonzero) revenue target in obviously essential, for otherwise distortion minimizing taxes could just be reduced to zero. This implies that solution to the optimal taxation problem will depend on the size of the revenue requirement, and more importantly, any changes in taxes should be revenue-neutral. Now consider a hypothetical tax reform of a wage tax cut. One can demarcate the effects of a tax cut into income and substitution effects. The income effect of the tax cut is that it increases after-tax income which in turns increases the taxpayers' time allocation to leisure in pursuit of enjoying increased consumption. On the other hand, the substitution effect of the tax cut is that marginal return to work becomes high which encourages more work. The net incentive effect of the tax cut, in principle, could go either way, depending on the relative strengths of the income and substitution effects. With revenue-neutral taxation, however, the average taxpayer's income effect is embedded in the loss or gain of welfare through fall or rise in consumption. Only the substitution effect will operate in factor allocations, implying that the tax cut will increase total labor supply.

If the wage tax is the only tax instrument, modelling disincentive effect is therefore simple. With multiple taxes, being selective in disincentive effects is actually necessary for tractability. To illustrate it further, consider the same example, now with a broader set of taxes that include capital tax and consumption tax. With revenue-neutral taxation, a wage tax cut financed by an instantaneous increase in the capital tax rate, for instance, will induce increased labor supply due to the substitution effect. But in this case the effect on consumption vis a vis welfare becomes ambiguous. Higher capital tax reduces savings, which adversely affects intertemporal consumption decision. A cut in wage tax at tandem on the other hand provides higher disposable income for consumption. Unless one is able to numerically characterize the welfare effect, it is analytically inconclusive which effect dominates.

It is widely accepted that tax reforms should be guided by the motivation to improve economic efficiency, i.e. the net incentive effect of a tax reform should be positive. This motivation is desirable from both normative and positive viewpoints. This is the central underlying principle of second best taxes. However, not all tax reforms can be straightforwardly interpreted as efficiency enhancing. First of all, for most general taxpayers it is not simple to identify a cut in average tax rate from a 
tax reform, unless the taxation authority cuts marginal tax rate keeping everything else unchanged. Income tax reforms, particularly in the UK, generally implement a number changes in different tax instruments including personal allowances, national insurance contributions, tax bands, tax credits etc. keeping the marginal tax rate unchanged. Allegedly, these reforms are directed towards enhancing growth and welfare by increasing real income and consumption. In other words these changes are expected to lower the average effective labor tax rate and increase disposable income and consumption. But then, in practice it is not straightforward to make clear that a tax reform implementing a tax cut is actually inducing real gains in welfare. This is because there are other taxes on transactions, such as consumption and capital taxes, and one needs to consider the changes in those taxes in order to evaluate the net incentive effect of a tax reform. This is where one starts worrying about the net price effect due to a tax reform, i.e. the relative strengths of income and substitution effects due to a tax reform.

Measuring the real net incentive effect of a tax reform can be complicated. The 2006 UK budget, for instance, implements a higher personal allowance on income tax, a higher tax base limit for income tax and higher levels of tax credits, but at tandem increases the national insurance contributions, inheritance tax threshold and job seekers' allowance. The implemented increase in personal allowance ranges from $£ 140$ to $£ 200$ depending on age. The budget also implements an increase in the income tax starting rate (10\%) limit from $£ 2,090$ to $£ 2,150$ and the basic rate (22\%) limit from $£ 32,400$ to $£ 33,000$. This is accompanied by a simplified pension tax regime which removes the pension scheme earning cap. In order to index for inflation, national insurance contributions are to increase within a range of $£ 2$ to $£ 15$ per week. This is accompanied by increases in the working and child tax credits within a range of $£ 20$ to $£ 75$ per year, increase in job seekers' allowance and a $£ 10,000$ higher threshold for inheritance tax. The combined effect of these reforms, as reported in the budget 2006 RIA, is essentially a cut in effective labor tax rate and a consequent increase in all levels of disposable income. The rate at which lower disposable income levels (with gross income up to $£ 20,000$ per year) is expected to grow ranges between $0.3 \%$ to $2.7 \%$ per year relative to previous levels of disposable income, while for higher levels of income this expected growth rate ranges between $0.2 \%$ to $0.4 \%$.

If for instance, one assumes that this reform is revenue neutral, the net incentive effect of this reform is likely to encourage more work and higher disposable income. Since general consumption taxes are more or less unchanged, as long as inflation is within target this reform is also likely to encourage more consumption. This is true even if one relaxes the assumption of revenue neutral taxation and allows for a distinct income effect of this tax cut. This analysis is based on intuitions from simple public economic theory, and given the RIA computations such a reform is consistent with Ramsey principles. Now, in addition to this reform in labor tax, consider replacing the $0 \%$ starting rate of corporation profit tax and the starting marginal relief of corporation profit tax by a single $19 \%$ small companies' profit tax for all companies with reported profit of $£ 0$ - 300,000 . 
This simplification allegedly allows small companies to focus on growing their businesses, increasing (and investing) their profits by reducing their administrative burden, and providing innovations and efficiency gains of their own. In turns, this simplification is likely to present a strong competitive challenge to incumbent firms who are in turn prompted to improve productivity.

But this reform would also mean that companies with profits of less than $£ 50,000$ per year could have a tax increase, depending on their current profit distribution policy. With this reform in corporation tax policy, the tax incentive to retain profits or making non corporate distributions would be removed; implying that small investors, or small family run businesses, or companies with sole traders or small partnerships, with under $£ 10,000$ profits who do not make distributions would incur an increase in capital tax rate from $0 \%$ to $19 \%$. In addition to these reforms capital gains tax annual exempt amount has been increased in line with statutory indexation and first year capital allowances to small businesses are increased from $40 \%$ to $50 \%$ for investment in plant and machinery. But after all, people pay taxes. Neither the statutory indexation of capital gains tax exempt amount nor the increase in capital allowances is likely to make up for the increase in effective capital tax rate at the household level. Although the intention of the reform is to promote growth in small businesses by boosting incentives to reinvest profits, an increase in effective capital tax rate is likely to reduce household savings and future levels of consumption. Any increase in effective capital tax rate is inconsistent with Ramsey principle, and I will discuss this inconsistency in some more detail in the next section. The net effect on aggregate consumption (and growth) due to the UK 2006 tax reform depends on many details, and tracking it accurately from a reduced form model is complicated. This is mainly because of the complexity associated with incorporating all tax instruments within the average effective tax schedules in a Ramsey taxation model.

I acknowledge that the mapping and tractability justifications are too simplistic relative to the importance of identifying accurate measures of incentive effects of tax reforms. These arguments are therefore likely to be insufficient to stifle the criticisms based on Ramsey tax rules' selective attention to disincentive effects. A tax reform with significant net disincentive effects will necessarily be welfare-worsening, and with selective attention to disincentive effects one runs the risk of overrating a Ramsey policy while some other policy could attain a higher level of welfare. Wynne (1997) presents a calibrated version of growth, welfare, and disincentive effects of hypothetical tax reforms in the US economy using a simple endogenous growth model. The calibration, for instance, suggests that halving the labor tax rate and financing it by an increase in the capital tax induces a $17 \%$ loss of initial consumption (a welfare loss) and slows the economic growth rate from $1.7 \%$ to $1.5 \%$. By contrast, a same cut in labor tax financed by an increased consumption tax boosts economic growth from $1.7 \%$ to $2.8 \%$, and increases welfare by increasing initial consumption by a massive $39 \%$. In terms of incentive effects, both policies increase labor supply but by different amounts. The capital tax increase causes labor supply to increase by $8 \%$, but the consumption tax increase results in a $14 \%$ increase in labor supply. 
Such results are interesting but they necessarily establish that determining growth and welfare effect, which are due to tax induced changes in incentives to work, consume or save, is far from simple. A significant part of Stokey \& Rebelo's (1995) paper is devoted to documenting this proposition in a purely technical manner, and like many I rate their paper to be one of extreme significance in understanding the incentive effects of taxes and how such effects should guide tax reform proposals. According to their findings, growth effects of a particular tax policy is highly sensitive to, among others, elasticity of intertemporal substitution and long run elasticity of labor supply, both of which are closely related to incentive effects of tax reforms through their effect on beliefs about changes in the interest rate. Since interest rate governs intertemporal allocation decisions, a tax reform that affects the interest rate will have long run incentive effects, and hence long run effects in growth and welfare.

\section{Capital Income Tax Policy}

It is a widely accepted hypothesis that capital income taxes are bad. In a competitive economy capital income tax drives a wedge between pre-tax capital rental rates and the intertemporal marginal rate of substitution between consumption at different dates. The wedge grows at a compounding rate over time which is inconsistent with commodity tax principle (see for instance, Judd (1999 \& 2002) and Mulligan (2003) for details). It is largely because of this underlying economic intuition policymakers and economists unanimously hold the principle that capital income should receive tax-favoured treatment.

Perhaps the most celebrated finding of the dynamic optimal taxation literature is that with competitive markets the long run optimal capital tax is equal to zero. Judd (1985) and Chamley (1986) are the promoters of this idea, who seminally established that in a standard neoclassical competitive growth model where the government's commitment power is perfect, the Ramsey rule is consistent with a long run zero capital tax. Jones et al. (1993) and Jones et al. (1997) establish that this principle extends to an economy with human capital and endogenous growth. Atkeson, Chari and Kehoe (1999) show that this result is robust in a wide variety of neoclassical growth models. With a zero tax in the limit, the optimal capital income tax policy may be frontloaded, i.e. the optimal policy may involve high taxes on initial capital that raise more than the required revenue, and zero taxes thereafter that avoids non-uniform distortions.

Optimality of zero capital income tax contradicts the conventional view in the public finance literature that capital income should be taxed heavily. As in the traditional public finance literature, if one assumes that savings rate is a fixed fraction of income, capital income tax does not distort economic decisions, and thus are desirable. But in a model where consumer chooses savings rate to maximize their utility from consumption over time, the Chamley-Judd result makes perfect sense. Judd (1999) explains this result for a simple tax on savings, but the intuition applies similarly 
to a tax on the return to capita $!^{9}$ Ever since its induction, this result has had the privilege of being one of the most popular and powerful policy lessons drawn from the Ramsey tradition. A tax reform that reduces the average capital tax is convenient (i.e. administratively less costly), more desirable (i.e. fairer), efficient (i.e. little or no disincentive effects) and politically acceptable (i.e. implementable). In fact simplifying the capital tax codes and relying less on capital income taxation has been the trend in OECD tax reforms over the last decade or more10.

With monopoly (or most pre-existing) distortions, the Ramsey rule generally does not prescribe a zero capital income tax although the tax favoured treatment to capital argument gets a stronger ground. Pre-existing distortion like monopoly pricing induces a loss in output and drives a wedge between private returns and socially optimal returns to capital and other factors. This implies that tax policy may use subsidies to bring buyer price down to social marginal cost. The subsidy result cannot be generalized for all transactions, since there is a concern of raising enough revenue to use corrective subsidies. The optimal policy therefore must choose some transactions to tax in order to subsidize other transactions. Since capital income tax induces non-uniform distortions in intertemporal allocation decisions, and consumption tax and labor taxes induce uniform distortions, Judd (1997) argues that the optimal policy is the one that subsidizes capital and taxes consumption and laboun 11

Such capital subsidies are often deemed as a costly alternative of other competition enhancing policy options. Auerbach \& Hines Jr. (2001), for instance, argue that antitrust policy can be more cost effective as a policy for enhancing competition and correcting monopoly induced distortions. Antitrust policy has intrinsic restrictions of application. Monopoly power in pricing may be attributable to many circumstances, one of which is product differentiation. Distortions of such various forms actually limit the general implications of competition enhancing antitrust policy. For instance, if there are fixed costs of production, competition cannot push price down to marginal cost, and having firms specialize in differentiated goods is desirable. If one extends the model of Judd (1997) to include innovation, even then antitrust policy would be of dubious significance since

\footnotetext{
${ }^{9}$ Judd's (1999) main intuition is that If the utility is separable across time and between consumption and leisure, and the elasticity of demand for consumption does not change over time, the best tax system would have a constant commodity tax equivalent. The dynamic version of the commodity tax principle is that optimal taxes should induce smooth and uniform distortions over time. Since the commodity tax equivalent of a capital income tax compounds over time, a nonzero capital income tax cannot be optimal.

${ }^{10} \mathrm{With}$ less than perfect commitment power policy relevance of this result is weaker. If the government frequently changes announced policies, an announcement of zero capital tax in future is not a credible announcement. If the government announces the policy and future becomes present when capital has been accumulated, supply of capital is inelastic, and the optimal policy becomes the one that taxes it. If the government can change its plan (or has a reputation of changing plans), capital owners are perfectly aware of the ex post optimal policy. Thus a zero capital tax announced today will not boost investment.

${ }^{11}$ Two years later Guo \& Lansing (1999) show that the long run optimal capital income tax rate with imperfectly competitive markets balances underinvestment effect and a profit effect. The government is motivated to tax capital since agents may over-invest in search of pure profits. On the other hand, due to discouraging private return to capital, there remains a motivation to use capital subsidy. Their result suggests that the sign of the optimal capital income tax rate is ambiguous, and depends on the relative strength of underinvestment effect and profit effect, or more intuitively, on the deviation of equilibrium investment from socially optimal level of investment.
} 
the point of a patent is to give incentives for innovations. With no fixed costs and innovation, Judd (1997) shows that product differentiation induced monopoly distortions in capital goods market are more damaging than those in consumer goods market, implying that antitrust policy should give priority to intermediate goods market.

One of Judd's (1997) conclusions was that capital income subsidies could be paid directly to the investors, or to the firms in the form of investment tax credits or accelerated depreciation schedules. Since equipment markets are more distorted by market power, the capital subsidy should look similar to the investment tax credit (ITC) for new equipment, which has been occasionally part of the US tax code $\notin^{12}$ Guo \& Lansing (1999) establish that the optimal capital subsidy result is a qualification of a much broader nonzero capital tax result. They model a capital tax code that involves depreciation allowance as a means to subsidize part of capital income ${ }^{13}$. Essentially, these two results are complementing, and the two effect result is the more general version of Judd's (1997) optimal capital subsidy result.

Tax reforms in most industrialized countries have shown clear tendency of moving towards simplistic capital tax policy involving lower (or no) amount of direct subsidy to capital and minimum amount of deductions. The main two objectives behind these reforms are (a) to encourage competition and innovation amongst firms, and (b) to increase the amount of corporation tax revenue. Various incentive schemes including investment tax credits and property related tax shelters have been moderated or abolished in numerous countries, such as Australia, Austria, Finland, Germany, Iceland, Ireland, Portugal, Spain and the USA. In addition, with a view to increasing corporate tax revenue some countries have reduced their corporate tax rate. The essential idea is that lower corporation tax rates provide lesser incentives for corporations to hide profits or evade taxes. Examples of this trend include Ireland (38\% to $12.5 \%$ ), Australia (36\% to $30 \%)$, Denmark (32\% to $30 \%)$, France (37.8\% to $35.4 \%)$, Germany ( $52 \%$ to $39 \%)$, Iceland $(30 \%$ to $18 \%$ ) and the Czech Republic (31\% to $26 \%$ ), of which Iceland, Ireland, Denmark, France and the Czech Republic have experienced immediate effect of an increase in corporate tax receipts. But this increased receipt may well be at the cost of increasing the effective capital tax rate. Due to the cut in corporation tax rates, there has been a mixed response in the effective capital tax rates in these countries. For instance, this figure has increased from $18.6 \%$ to $18.7 \%$ for Ireland, from $19.2 \%$ to $23.1 \%$ in Czech

\footnotetext{
${ }^{12}$ The ITC was an on-and-off policy device in the US. Its political sensitivity, and acceptability in general, is of some doubt. It was introduced in 1962, repealed in 1969, reintroduced in 1971, and finally eliminated in 1986. According to this policy firms receive a tax credit proportional to their purchase of new equipment but not structures. The ITC fluctuated between and until 1986 when it was completely eliminated. The US code currently includes a tax credit for qualifying expenditures on research and development activities. In the UK, a similar subsidy to capital investment is paid through corporate grants for the purchase of new capital goods. This policy was first introduced in 1967 and is still in practice.

${ }^{13}$ Depreciation allowances in excess of economic depreciation are another form of investment subsidy which is in practice, in a rather generous fashion, in both the US and the UK tax codes. For instance in the UK, starting from 1972 the initial allowance received by industrial buildings ranged between $40 \%$ and $75 \%$. Inventories received tax relief due to high inflation in the 1970s. According to the US corporate tax structure, physical rents from capital are taxed at a constant rate after the allowance of a deduction for depreciation.
} 
Republic, and from $22.9 \%$ to $23.6 \%$ in France. By contrast, there has been a decline in the effective capital tax rate in Germany (21.1\% to $19.9 \%$ ), while in Australia it has remained unchanged at $28 \%$ (see for details, Carey \& Tchilinguirian (2000)).

If one considers capital movements across borders, the zero capital tax result is essentially the stronger one. In an integrated world where capital is relatively more mobile across borders, any tax on capital will shift capital from taxed country to an untaxed country. There are a number of channels through which domestic taxation of capital exerts international effects. For instance, domestic taxes affect the international allocation of the existing stock of world capital. These taxes also affect international growth and the process of capital accumulation over time. A country's capital tax reforms can influence the level of savings both at home and abroad, which in turn affects international rate of capital accumulation and economic growth. Moreover, domestic taxation of capital can be associated with different effects on economic growth and welfare. This may seem quite obvious since in an open economy tax reforms result in two distinct effects: one on domestic product, and the other on national income. Changes in welfare due to capital tax reforms induce important distributional effects, since such reforms have different effects on welfare of individuals at home and abroad.

Two country models with overlapping generations has been quite popular in investigating a broad range of issues related to international capital taxation. An important contribution to this trend is Sibert (1985), which examines foreign investment taxation as a means to restricting capital mobility in a two country overlapping generations model. The main idea of Sibert (1985) is that since the degree of capital mobility affects gains from trade, incentive effects of capital accumulation, and intergenerational welfare, restricting capital mobility through foreign investment taxation affects all three. More specifically, Sibert (1985) shows that at least one country's welfare is improved by taxation, and since investment taxation adversely affects savings rate, generational preference for a smaller or larger tax on foreign investment depends crucially on generational location which may be a capital-exporting or capital-importing country. The steady state incentive effects across borders also vary considerably for location-specific choice of small or large taxes. For instance, if the home country implements smaller taxes for home investors on the after-tax earnings from exported capital, the long run levels of foreign rental price of capital rises and home rental price of capital falls. Converse happens if the foreign country imposes a smaller tax on the earning of imported capital.

The welfare effects of capital taxation in a large open economy have been examined and analyzed in a number of important papers. Palomba (2004) examines both the welfare and growth effects of international capital taxation, but the paper delivers much less robust policy prescriptions as compared to what closed economy models generally do. Nevertheless, there is one finding which is common in Palomba (2004) and its peers: in an open economy, there is a distinction between the effect of taxes on domestic product and the effect of taxes on residents' claims on that product 
(national product). For instance, a country can increase domestic productivity and the growth rate of its product by lowering its taxes, but this may lower the level of domestic saving, which in turns reduces the claims of its citizens on future product and their welfare. Moreover, international tax interdependencies pose subtle problems of policy design to national governments. Governments may use taxes on capital income both to compete for the existing stock of world capital and to affect the rate of capital accumulation over time. But a policy that increases the domestic share of current capital may not increase the growth rate of that capital in future.

Furthermore, there are important issues related to cyclical properties of tax reforms, much of which is the main agenda in stochastic versions of two country models. Kim \& Kim (2005), for instance, develop an infinite horizon stochastic general equilibrium model of optimal taxation in two countries, and examine the possibility of welfare-improving active, contingent tax policies. They find that the cyclical properties of optimal tax rules can be significantly different in a closed and an open economy setting. More precisely, in a closed economy setting, optimal tax policy is countercyclical in capital income taxes, implying that optimal tax response to an increase in productivity is to increase capital tax rate. However in the open economy setting where capital moves across borders, optimal tax policy becomes procyclical in capital income taxes. The procyclical tax policy generates efficiency gains by correcting market incompleteness.

\section{Ramsey Policy in Developing Economies}

The leap from the doctrines to the real world is a large one when it comes to taxation, and a larger one when it comes to taxation in developing economies. Implementing an optimal tax policy in developing countries is subject to many hurdles, some of which have not been highlighted or analyzed so far in this paper. For instance, there is a predominantly active informal sector in these countries, and transactions of such a sector cannot be taxed by the government. This amounts to incomplete taxation of factors, which in turns is likely to change the standard Ramsey tax principles and composition of revenues. In designing tax policy, developing countries must also consider the margin of deviation from tax system in other countries. This is because with commercial integration there is an issue of designing tax policy that is conducive to foreign investors and expatriate workers. Such integration also raises concerns of raising revenue with much less reliance on foreign trade taxation.

Most workers in developing countries are typically employed in agriculture or in small informal enterprises. Looking at the International Labor Organization (ILO) 2002 report, on an average more than half of the total workforce of South Asian developing countries is employed in informal sectors. For India, Pakistan, Nepal and Bangladesh, this figure stands at 56\%, 65\%, 74\% and 59\%, respectively. The predominance of informal sector employment is also observed in other developing countries, such as $75 \%$ in Ethiopia, $72 \%$ in Lithuania, $37 \%$ in Kenya, $32 \%$ in Mexico, and $43 \%$ 
in Fiji. As workers in the informal sector are seldom paid a regular, fixed wage, their earnings fluctuate. Because of surplus (or family) labor, in some cases their real marginal wage is zero, or some form of payment which is off the books. The base for an income tax in such economies is therefore difficult to calculate. Moreover, workers in these countries generally do not spend their earnings in large stores that keep accurate records of sales and inventories. As a result, modern means of raising revenue, such as income taxes and consumption taxes, play a rather vague role in these economies.

Informal production sector has been formally modelled in the recent optimal taxation literature, albeit with simple technology and very selective focus on its consequences in fiscal policy. Penalosa \& Turnovsky (2005) develop a two-sector model of Ramsey taxation where they assume that economic activities in one sector are informal, i.e. non-taxable by the government. Their model is in the spirit of Jones et al. (1993), but due to private factor allocation in informal sector their main attention is on optimal incomplete taxation. The main motivation of Penalosa \& Turnovsky (2005) is to establish the Ramsey tax principles for developing countries. Saying that their simple model provides some very useful insights in pursuit of a rather obscure policy design problem will not be an overstatement. For instance, one of their findings is that the optimal capital tax in such a setting is nonzero irrespective of how the revenues are used. Moreover, the welfare maximizing labor tax and capital tax rates depend crucially on how the government uses the tax revenue, which may be simple redistribution, or investment in infrastructure.

Implementing an optimal tax policy in developing countries is also subject to problems related to tax administration, some of which are of peculiar nature. It is difficult to create an efficient tax administration without a well educated and well trained staff, when money is lacking to pay good wages to tax officials and to computerize the operation, and when taxpayers have limited ability to keep accounts. There are concerns of corruption in tax administration and tax collection, a high tendency of tax evasion, and strong and influential corporate lobbies which, through campaign contribution, almost determine the policy to be implemented. Moreover, because of the informal structure of the economy and financial limitations, in many developing countries statistical and tax offices have inflexibility in generating and documenting reliable statistics. This lack of data prevents policymakers from assessing the potential impact of major changes to the tax system. As a consequence, marginal changes are often preferred over major structural changes, even when the latter are clearly preferable.

A relatively more globally integrated developing country faces, on top of what has been discussed so far, another subset of problems in designing tax policy. The world price of an imported capital good is the social cost of capital for a small developing country. In such a case the optimal capital subsidy result does not apply, since the country should not subsidize imported capital goods as long as its internal price equals the world price. This implies that policies like investment tax credit or any other investment subsidy have little scope in neutralizing monopoly distortions. This situation 
is further complicated if there are foreigners who own a domestic firm in a developing country which produces a monopolized capital service. Since the rent goes to the foreigners, the true social cost to the developing country is the monopoly price, which cannot justify the optimal capital subsidy principle. Finally, income tends to be disproportionately distributed within developing countries. Although raising high tax revenues in this situation ideally calls for the rich to be taxed more heavily than the poor, this is rarely reflected in their fiscal policy designs and reforms. The economic and political power of rich taxpayers often allows them to prevent fiscal reforms that would increase their own tax burdens. This problem is analogous to the influential corporate lobbying problem, and it is creating issues in industrialized countries as well. But the lobbying problem in developing countries have the worse effect, since it explains, albeit in part, why many developing countries have not fully exploited personal income and property taxes, and why their tax systems rarely achieve reasonable progressiveness.

\section{Concluding Remarks}

This paper has attempted to establish the policy relevance of optimal tax rules drawn from the Ramsey tradition. It has analyzed the technical importance of Ramsey tax rules in practical policy design. One of its main purposes, though expressed in a subtle tone in its contents and discussions, was establishing a practical and rather impartial viewpoint towards the Ramsey tradition of optimal taxation. It was certainly not the intention of this paper to campaign for Ramsey tax rules by criticizing its substitutes or complements. Along the discussion, the paper has attempted to establish an unbiased view towards the importance of optimal tax rules in general, i.e. it has highlighted the strengths and usefulness of Ramsey tax rules as part of a set of efficient tax prescriptions. It has argued in favour of Ramsey tax rules by refuting its common criticisms only to highlight Ramsey tax rules' value and significance in practical policy design.

What this paper has argued is that Ramsey tax rules that summarize the optimal average taxes are important and relevant in designing fiscal policy, but they serve moderately to provide guidelines and insights into specific design of taxes. A Ramsey tax rule illustrates the macroeconomic tax rate on a taxable transaction which in turn reflects the optimal proportion of that particular transaction to be taxed. Given this formulation, and given the welfare maximizing objective, Ramsey tax rules are simply the normative benchmark level of effective tax rates which are not subject to criticism from positive policy design perspective. A Ramsey tax rule can be practically implemented with a combination of different tax instruments; it is inappropriate to criticize a Ramsey model only because it serves little to find the right combination of specific tax instruments that achieves a

Ramsey tax rule.

This paper attaches a relatively high weight on the policy relevance of Ramsey rule for capital taxation. The underlying intuition of the two most popular results in this issue is clear and attracts 
widespread acceptability. The Ramsey rule for labor taxation is drawn from Ramsey's original inverse elasticity rule. In a dynamic economy optimal labor taxes with competitive markets should be smooth and roughly constant over time. This result stands robust for standard Ramsey tax models, and proponents of flat rate taxes also support this rule on grounds of intra and intertemporal smoothing of consumption and labor allocation decisions. With imperfect competition, the optimal levels of labor tax rates are lower than what it would have been under perfectly competitive markets. This result reflects the differential tax treatment of labor working under monopoly power in pricing and/or wage setting.

The optimal policy for wage taxation is much debated on its progressivism, an issue which is much better handled in the Mirrlees tradition of optimal taxation. The degree of abstraction often embedded in Mirrlees tradition's models of optimal nonlinear taxation, however, may limit the policy relevance of their results. For instance, one often cited result is that the marginal tax rate on the highest income person, who presumably has the highest ability, is zero. The intuition behind this result is that a nonzero marginal tax rate distorts the labour supply of the highest ability person. If this tax rate were changed to zero, the highest ability person might work more, which would make that person better off. However, government revenue would not change, because with a positive tax rate this labor is not provided, and with a zero tax rate the extra labor supply is not taxed. The logic of this argument applies only at the top of the income distribution, because changes in marginal tax rates below this level affect the taxes paid by people with higher incomes. This result however does not give any information about how high marginal tax rates should be just below the top of the income distribution. Also, from a practical standpoint, it is almost impossible to determine the top of the ability or income distribution.

\section{Bibliography.}

[1] Alm, J. (1996). 'What is an "Optimal" Tax System?', National Tax Journal, Vol. 49, pp. 117-133. Further Information

[2] Atkeson, A., Chari, V. V. \& Kehoe, P. J. (1999). 'Taxing Capital Income: A Bad Idea', Federal Reserve Bank of Minneapolis Quarterly Review, Vol. 23, pp. 3-17. Further information in IDEAS/RePEc

[3] Auerbach, A. J. \& Hines, J. R. Jr. (2001). 'Taxation and Economic Efficiency', NBER Working Paper, No. 8181. Further Information

[4] Ballard, C., D. Fullerton, J. B. Shoven, and J. Whalley (1985). A General Model for Tax Policy Evaluation. Chicago: University of Chicago Press for the National Bureau of Economic Research, 1985.

[5] Bickley, J. M. (2004). 'Flat Tax Proposals and Fundamental Tax Reform: An Overview', CRS Issue Brief for Congress, IB95060, Government \& Finance Division. Further Information

[6] Chamley, C. (1986). 'Optimal Taxation of Capital Income in general Equilibrium with 
Infinite Lives', Econometrica, Vol. 54, pp. 607-622. Further information in IDEAS/RePEc

[7] Guo, J-T. \& Lansing, K. J. (1999). 'Optimal Taxation of Capital Income with Imperfectly Competitive Product Markets', Journal of Economic Dynamics and Control, Vol. 23, pp. 967-995. Further information in IDEAS/RePEc

[8] Heady, C. (1993). 'Optimal Taxation as a Guide to Tax Policy: A Survey', Fiscal Studies, Vol. 14, pp. 15-41. Further information in IDEAS/RePEc

[9] Jones, L. E., Manuelli, R. E. \& Rossi, P. E. (1997). 'On the Optimal Taxation of Capital Income', Journal of Economic Theory, Vol. 73, pp. 93-117. Further information in IDEAS/RePEc

[10] Judd, K. L. (1985). 'Redistributive Taxation in a Simple Perfect Foresight Model', Journal of Public Economics, Vol. 28, pp. 59-83. Further Information

[11] Judd, K. L. (1999). 'Optimal Taxation and Spending in General Competitive Growth Models', Journal of Public Economics, Vol. 71, pp. 1-26. Further information in IDEAS/RePEc

[12] Judd, K. L. (2002). 'Capital Income Taxation with Imperfect Competition', The American Economic Review, Vol. 92, pp. 417-421. Further information in IDEAS/RePEc

[13] Judd, K. L. (2003). 'The Optimal Tax Rate for Capital Income is Negative', NBER Working Paper W6004 (1997), Hoover Institution Version 2003. Further information in IDEAS/RePEc

[14] Kim, J. \& Kim, S. H. (2004). 'Welfare Effects of Tax Policy in Open Economies: Stabilization and Cooperation', Working paper in Economics, Department of Economics, Tufts University. Further information in IDEAS/RePEc

[15] Ljungqvist, L. \& Sargent, T. J. (2000). Recursive Macroeconomic Theory. London: The MIT Press, 2000. Further Information

[16] Mayshar, J. (1991). 'Taxation with Costly Administration', Scandinavian Journal of Economics, Vol. 93, pp. 75-88. Further information in IDEAS/RePEc

[17] Minford, P. (2006). 'An Agenda for Tax Reform', CPS Policy Papers, Centre for Policy Studies. Further Information

[18] Mirrlees, J. A. (1971). 'An Exploration in the Theory of Optimal Income Taxation', The Review of Economic Studies, Vol. 38, pp. 175-208. Further information in IDEAS/RePEc

[19] Palomba, G. (2004). 'Capital Income Taxation and Economic Growth in Open Economies', IMF Working Paper, WP/04/91. Further information in IDEAS/RePEc

[20] Penalosa, C. G. \& Turnovsky, S. J. (2005). 'Second Best Optimal Taxation of Capital and Labor in a Developing Economy', Journal of Public Economics, Vol. 89, pp. 1045-1074. Further information in IDEAS/RePEc

[21] Piggot, J. and J. Whalley (1985). UK Tax Policy and Applied general Equilibrium Analysis. Cambridge: Cambridge University Press. Further Information

[22] Ramsey, F. P. (1927). 'A Contribution to the Theory of Taxation', The Economic Journal, Vol. 37, pp. 47-61.

[23] Regulatory Impact Assessments (RIA), Various Issues, Reference Documents, http://www.hmrc.gov.uk 
[24] Renstrom, T. I. (1999). 'Optimal Dynamic Taxation' in S. B. Dahiya, eds., The Current State of Economic Science, Spellbound Publications, 1999. Further Information

[25] Shapiro, R. J. (1996). 'Why Fairness Matters: Progressive Versus Flat Taxes', in Taxes $\&$ The New Economy, Progressive Foundation, 1996. Further Information

[26] Shavell, S. (1981). 'A Note of Efficiency vs. Distributional Equity in Legals Rulemaking: Should Distributional Equity Matter Given Optimal Income Taxation?', The American Economic Review, Vol. 71, pp. 414-418. Further information in IDEAS/RePEc

[27] Sibert, A. C. (1985). 'Capital Accumulation and Foreign Investment Taxation', The Review of Economic Studies, Vol. 52, pp. 331-345. Further information in IDEAS/RePEc

[28] Slemrod, J. (1990). 'Optimal Taxation and Optimal Tax Systems', The Journal of Economic Perspectives, Vol. 4, pp. 157-178. Further information in IDEAS/RePEc

[29] Stokey, N. L. \& Rebelo, S. (1995). 'Growth Effects of Flat-Rate Taxes', The Journal of Political Economy, Vol. 103, pp. 519-550. Further information in IDEAS/RePEc

[30] Wynne, M. A. (1997). 'Taxation, Growth and Welfare: A Framework for Analysis and Some Preliminary Results', Economic Review, First Quarter, pp. 1-13, Federal Reserve Bank of Dallas. Further information in IDEAS/RePEc

[31] Yitzhaki, S. (1979). 'A Note on Optimal Taxation and Administrative Costs', The American Economic Review, Vol. 69, pp. 475-480. Further information in IDEAS/RePEc 
Please note:

You are most sincerely encouraged to participate in the open assessment of this discussion paper. You can do so by posting your comments.

Please go to:

www.economics-ejournal.org/economics/discussionpapers/2007-31

The Editor

www.economics-ejournal.org 